\title{
Morphological Structure of Polystyrene Degradated by Soil Bacteria from Sarimukti Final Landfill Cipatat Bandung
}

\author{
Tri Rahayu Hidayat ${ }^{1}$, Ida Indrawati ${ }^{2}$, Tati Herlina ${ }^{3)}$ \\ 1,2Departement of Biology, Faculty of Matematics and Natural Sciences, \\ University Padjadjaran \\ ${ }^{3}$ Departement of Chemistry, Faculty of Matematics and Natural Sciences, \\ University Padjadjaran \\ email: tri13011@mail.unpad.ac.id
}

\begin{abstract}
The amount of Styrofoam waste in Bandung reaches 27,02 tons per month. Styrofoam used as packaging food or drinks, that are formed on styrene and benzene. The migration of benzene from packaging materials to food can cause various diseases. The most potent source of finding indigenous bacteria that can degrade of synthetic polymers is in the Final Landfill. This research method uses exploratory methods that are analyzed descriptively consisting of the stages of the biodegradation test with the Winogradsky Column method, calculation of the percentage of weight loss of Styrofoam, physical analysis with Scanning Electron Microscope (SEM). The results of this study found 4 species of polystyrene degrading bacteria is Pseudomonas aeruginosa, Bacillus amyloliquefaciens, Bacillus cereus and Bacillus firmus. The percentage reduction in dry weight of polystyrene showed in the first week the polystyrene weight decreased by $8.27 \%$ and increased weight loss up to the eighth week which reached $18.23 \%$ and and physical analysis with Scanning Electron Microscope (SEM) indicates that the process of degradation by soil bacteria showed the formation of holes or pores on the surface. These polystyrene degrading bacteria from Sarimukti landfills can be recommended as an environmentally friendly method for reducing styrofoam waste.
\end{abstract}

Key words: Degradation, Morphological Structure, Polystyrene

\section{A. Introduction}

Styrofoam is widely used for various purposes, for example as a protective electronic material even for packaging food or drinks. This waste not only harms the environment but a negative impact on human health. The environmental impact of the small component of polystyrene, which is found on the surface and throughout the water column, is likely to be digested by marine organisms and is a threat to ecosystems in the ocean. If ingested by organisms, it can endanger the quality of marine catches. Other impacts can pose a risk to public health from eating fish and shellfish that have ingested polystyrene fragments (Brink, et al., 2016). Other health impacts, the International Agency for Research on Cancer (IARC) in 2014 determined that styrene is a carcinogen. This is 
based on the results of research on styrene metabolites (ie styrene oxide) as epoxides that are very chemically reactive, which can chemically bind to DNA and trigger carcinogenesis. Differences between individuals in metabolism can affect the effects of these carcinogens, as well as possible differences in susceptibility to carcinogenicity between species and individuals (NTP, 2014).

\section{Literature Review}

\section{Biodegradation}

The method of handling styrofoam waste which is limited to disposal will burden nature in its decomposition (Fitidarini and Damanhuri, 2011). Therefore, we need other methods that are environmentally friendly to reduce styrofoam waste. One method that can be done is through a biodegradation process that utilizes microorganisms that play a role in synthetic polymers in the environment. Bacteria are the most dominant group of microorganisms in the soil and cover half of the microbial biomass in the soil. Polymer biodegradation process can be carried out using Rhodococcus pyridinivorans (Kundu and Chaudhari, 2015). Pseudomonas putida and Pseudomonas aeruginosa (Hilliard and Jacob, 2015). Enterobacter sp., Citrobacter sedlakii, Alcaligenes sp. and Breyundimonas diminuta with a degradation rate of $12.4 \%$ for 30 days (Sekhar et al., 2016), Staphylococcus aureus and Streptococcus pyogenes (Asmita et al., 2015).

One type of bacteria that has been investigated for its ability to degrade polystyrene is Pseudomonas that generally does not have hydrolytic enzymes that are important in degrading polymers but have an inducible operon system that is capable of producing certain enzymes in the process of metabolizing carbon sources that are not normally used. The type of enzyme produced by Pseudomonas spp. which play a role in biodegradation are serine hydrolase, esterase, and lipase [4]. P. aeruginosa by changing polystyrene into acetyl CoA which enters the TCA cycle. The result of the degradation of styrene into acetyl CoA was not able to break the benzene compound, so the degradation of polystyrene with $P$. aeruginosa still leaves toxic compounds and not environment friendly (Nugraha, 2018).

\section{Morphological Structure of Polystyrene Degradated by Bacteria}

The process of biodegradation can be observed in the presence of bacterial biofilms in polystyrene. Characterization in the calculation of the percentage weight loss and physical analysis with Scanning Electron Microscope (SEM) indicates that the process of degradation by soil bacteria occurs. The control samples in the study showed a smooth surface while polystyrene with Pseudomonas and Bacillus treatments showed the formation of holes or pores on the surface, and indicated degradation. Percentage reduction in dry weight after incubation treatment was obtained by a decrease of $23.7 \%$ in Bacillus sp and less than 10\% in Pseudomonas sp. (Mohan et al., 2016). 
The purpose of this study was to characterize morphological changes from Polystyrene after degradation. The expected results are bacteria from FDS in Sarimukti soil that can degrade Polystyrene so that it can be used as a method to reduce Styrofoam waste.

\section{B. Methods}

This research was conducted at the Microbiology Laboratory of Departement Biology, Faculty of Mathematics and Natural Sciences, Universitas Padjadjaran and Pusat Survei Geologi, Bandung. The soil sample used in this study were collected from Final Landfill in Sarimukti, Bandung. Sample of Styrofoam is cut to a diameter of $2 \mathrm{~cm}$ and then sterilization. Biodegradation Test steps is bottles filled with $250 \mathrm{~g}$ of soil sample and $250 \mathrm{ml}$ of Mineral Salt Medium (MSM). Styrofoam is bottled then incubated at room temperature for 8 weeks (Sriningsih and Shovitri, 2015). Calculation of Percentage of Dry Weight Loss steps is pieces of Styrofoam are put into a tube each week with $13 \mathrm{ml}$ of sterile distilled water, then vortex, Styrofoam pieces are separated to be weighed (Ainiyah and Shovitri, 2014). Styrofoam pieces were sterilization, roasted at $80^{\circ} \mathrm{C}$ for 24 hours then measured to lose its dry weight (Sriningsih and Shovitri, 2015). Scanning Electron Microscope (SEM) Analysis steps is Styrofoam samples were sprayed with 70\% alcohol, placed on top of the SEM specimen holder using a carbon double type with a cross-section pointing vertically up or to the objective lens. The sample chamber is vacuum up to 10-6 torr. SEM is operated with standard operating parameters. Topographic images were observed (Sujatno et al., 2015).

\section{Results And Discussion}

\section{Biodegradation}

The Winogradsky column method is used for biodegradation testing. This method can show the ecological picture of soil bacteria in an ecosystem as well as the stratification of electron donors for each layer. The Winogradsky column method uses bottles filled with soil from the Final Landfill and Mineral Salt Medium (1:1). Soil is a source for bacteria that can degrade polymer because most bacteria from Final Landfill have adapted to their environment which has a lot of organic and inorganic waste including Styrofoam. MSM is used as a nutrient medium for growing bacteria but without a carbon source, then bacteria are expected to use a carbon source from polystyrene.

Microorganisms play a role in a biological degradation polymer. Bacteria will break down the polymer be the monomer used in its metabolism to produce energy sources. Biodegradation can occur due to cooperation between bacteria that can degrade polystyrene, the bacteria produce specific enzymes that can break down polystyrene into simpler styrene monomers. This decomposition process is environmentally friendly because bacteria will not produce harmful compounds when degrading the polystyrene. The results of isolation and identification of bacteria in this study obtained 4 species of 
bacteria, i.e Pseudomonas aeruginosa, Bacillus amyloliquefaciens, Bacillus cereus and Bacillus firmus.

Pseudomonas aeruginosa is a gram-negative bacillus found widely in nature, in soil and water. P. aeruginosa has few nutritional requirements and can adapt to conditions not tolerated by other organisms. It does not ferment lactose or other carbohydrates but oxidizes glucose and xylose. Organisms grow aerobically or anaerobically if nitrate is available as an inorganic electron acceptor (Planet, 2018). Most strains of P. aeruginosa produce one or more pigments, including pyocyanin (blue-green), pyoverdine (yellowgreen and fluorescent), and pyorubin (red-brown) (Wu et al., 2015). According to Siemering et al (2016), Bacillus amyloliquefaciens is a Gram positive and spore-forming bacteria that active in the soil root zone (rhizosphere), and commonly found in soil ecosystems.

Bacillus cereus is a Gram-positive, rod-shaped, facultative anaerobic bacteria that can produce toxins which cause food poisoning. It forming protective endospores, beta haemolytic activity, $B$. cereus is the most motile. $B$. cereus causes two types of illness; emetic (nausea and vomiting) and diarrhoeal. Infective dose of $B$. cereus is commonly associated with the consumption of $10^{5}-10^{8}$ organisms. The infective dose can vary depending on the amount of enterotoxin produced. B. cereus is widespread in the environment and can be isolated from soil and vegetation. It is found in a variety of foods which include rice and other starches; prepared foods such as soups, sauces and puddings; milk, meat and vegetables. The common factor in most cases of food-borne illness is the consumption of foods which have not been stored at temperatures less than $40 \mathrm{~F} / 4^{\circ} \mathrm{C}$ or above $140 \mathrm{~F} / 60^{\circ} \mathrm{C}$ (Osborne, 2013). Bacillus firmus is small to medium-sized, semi-transparent, flat colonies, Gram positive, long, spore forming, catalase positive and motile (Department of Veterinary Disease Biology, 2011).

\section{Calculation of Percentage of Dry Weight Loss}

Characterization of changes in morphological structure observed in this study, including the calculation of the percentage of dry weight loss in styrofoam and physical analysis using a Scanning Electron Microscope (SEM). The results of the calculation of the percentage of dry weight loss of styrofoam showed that after the incubation process in the first week had experienced a weight loss of styrofoam of $8.27 \%$. 


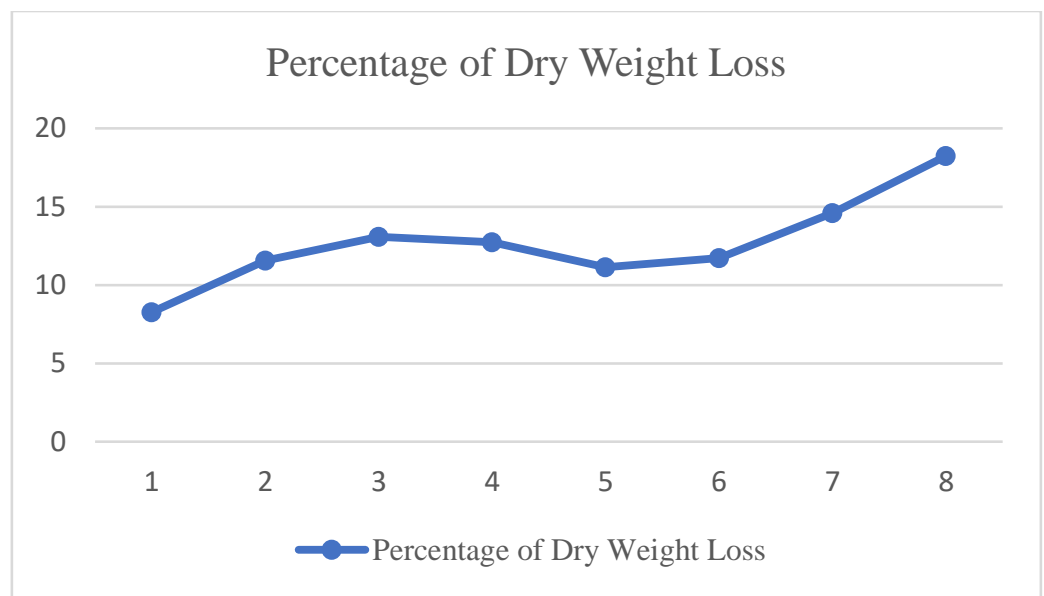

Figure 1. Percentage of Dry Weight Loss

This weight loss of styrofoam is caused by soil bacteria using polystyrene as a carbon source for its metabolism. This study uses a mineral salt medium, which is a medium without a carbon source that is used to form a bacterial environment and forces bacteria to use polystyrene as a carbon source for their metabolism. The first week there has been a loss of weight from Styrofoam. The graph of the loss of styrofoam dry weight percentage (Figure 1) shows an increase from the first week to the fourth week, the fifth week has a slight decrease, but has increased again in the sixth week until the eighth week that reaches $18,23 \%$. The changes that occur in the Percentage Styrofoam dry weight loss chart can be indicated due to changes in bacterial metabolic patterns, sensitivity characteristics, and antagonistic characteristics between bacterial species in the same environment.

\section{Scanning Electron Microscope (SEM) Analysis}

The direct and indirect effects of the bacterial degradation process on styrofoam can be seen after an incubation process for 1 week. Morphological changes that can be observed directly are changes in color, texture and formation of biofilms on the surface of the Styrofoam. Before incubating the styrofoam surface it has a clean white color with a smooth and flat texture, after incubating for 1 week the surface color of the styrofoam turns brown and has a rough and slimy texture. The change in color, texture and formation of mucus is due to the growth of Styrofoam degrading bacteria on the Styrofoam surface. The overall degradation process on the styrofoam surface as shown in Figure 2. 


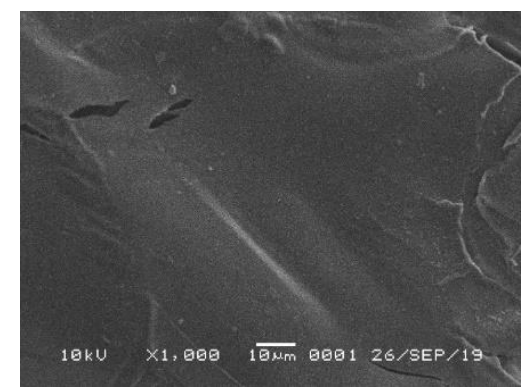

a. Before Degradation
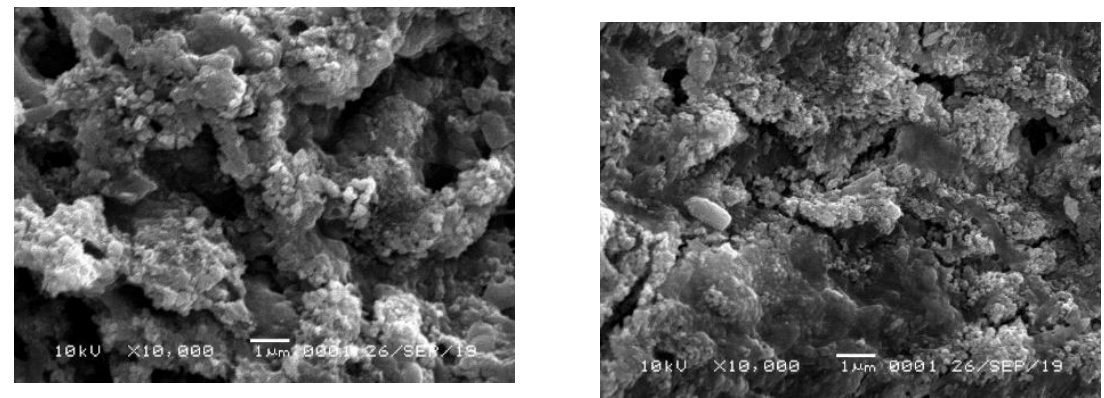

b. 1 week of degradation

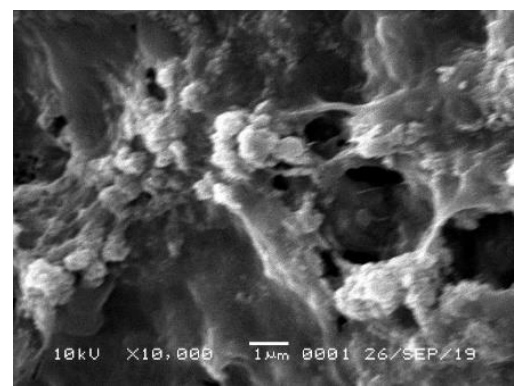

c. 3 week of degradation

d. 5 week of degradation

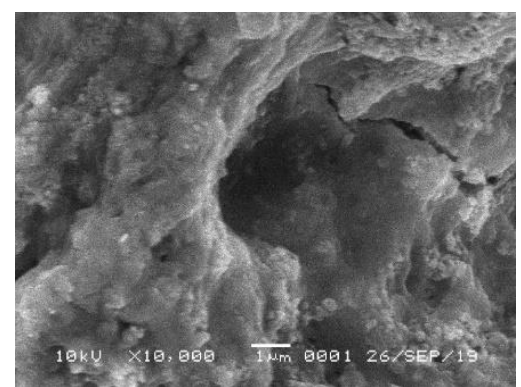

e. 7 week of degradation

Figure 2. SEM Photos of Degradation Process

Morphological changes can indirectly be seen through Scanning Microscope Electron (SEM), the results that can be observed from changes in styrofoam before incubation are smooth and flat surfaces, whereas after incubation there are holes and pores on the surface of styrofoam. The longer the incubation period, the bigger and wider the hole or pore that forms on the surface.

\section{Conclusion}

The results of this study found 4 species of polystyrene degrading bacteria is Pseudomonas aeruginosa, Bacillus amyloliquefaciens, Bacillus cereus and Bacillus firmus. The percentage reduction in dry weight of polystyrene showed in the first week the polystyrene weight decreased by $8.27 \%$ and increased weight loss up to the eighth week 
which reached $18.23 \%$ and and physical analysis with Scanning Electron Microscope (SEM) indicates that the process of degradation by soil bacteria showed the formation of holes or pores on the surface. These polystyrene degrading bacteria from Sarimukti landfills can be recommended as an environmentally friendly method for reducing styrofoam waste. 


\section{References}

1. Ainiyah, D., dan Shovitri, M. (2014). Bakteri Tanah Sampah Pendegradasi Plastik dalam Kolom Winogradsky. Jurnal Sains Dan Seni Pomits, 3(2), 3-6.

2. Asmita, K. Shubhamsingh, T. Tejashree, S. (2015). Isolation of Plastic Degrading Micro-organisms from soil samples collected at various location in Mumbai, India. Curr World Environmental. 4 (3), 77-85.

3. Brink, P. T., Schweitzer, J. P., Watkins, E., Gionfra, S. (2016). Plastics, Marine Litter and Circular Economy - Product Briefings. Institute for European Environmental Policy.

4. Department of Veterinary Disease Biology. (2011). Faculty of Health and Medical Sciences - University of Copenhagen. Denmark

5. Fitidarini, N. L., \&amp; Damanhuri, E. (2011). Timbulan Sampah Styrofoam di Kota Bandung. Jurnal Teknik Lingkungan, 17(2), 87-97.

6. Hilliard, R. and Jacob, J. R. (2015). The Effect of Limonene on the Biodegradation of Phenanthrene and Polystyrene by Pseudomonas putida and aeruginosa. in First Annual SUNY Undergraduate. Research Conference. New York.

7. Kundu, D. Hazra, C. And Chaudhari, A. (2015). Biodegradation of 2,4dinitrotoluene with Rhodococcus pyridinivorans NT2: characteristics, kinetic modeling, physiological responses and metabolic pathway. The Royal Society of Chemistry. 5, 38818-38829.

8. Mohan, A. J. Bhaskar, T. Sekhar, V. C. Nampoothiri, K. (2016). Microbial assisted High Impact Polystyrene (HIPS) degradation. Bioresourch Technology Journal. 213, 204-207.

9. NTP(National Toxicology Program.12th Report on Carcinogens,13th Edition. (2014). Research Triangle Park, NC:U.S. Department of Health and Human Services. Public Health Service [Internet]. Available from: http://ntp.niehs.nih.gov/ntp/roc/content/profiles/styrene.tif

10. Nugraha, I. K. (2018). Biodegradasi Oksidatif Styrofoam dengan Kapang Pelapuk Putih dan Bakteri. Departemen Biokimia FMIPA IPB. Bogor

11. Osborne, N. (2013). Fact sheet on Bacillus cereus. ThermoFisher Scientific. [Internet]. Available from: https://www.thermofisher.com/blog/food/fact-sheeton-bacillus-cereus/

12. Planet, J, Paul. (2018). Principles and Practice of Pediatric Infectious Diseases (Fifth Edition) : 155 - Pseudomonas aeruginosa. Science direct. 866-870.

13. Sekhar, V. C. Nampoothiri, K. Mohan, A. J. Nair, N. R. Bhaskar, T. and Pandley, A. (2016). Microbial degradation of High Impact Polystyrene (HIPS), an e-plastic with decabromodiphenyl oxide and antimony trioxide. Journal of Hazardous Materials. 
14. Siemering G, Ruark M, and Gevens A. (2016). The value of Bacillus amyloliquefaciens for crop production. University of Wisconsin System Board of Regents and University of Wisconsin-Extension, Cooperative Extension. 1-4

15. Sriningsih, A., dan Shovitri, M. (2015). Potensi Isolat Bakteri Pseudomonas sebagai Pendegradasi Plastik. Jurnal Sains Dan Seni ITS, 4(2), 67-70.

16. Sujatno, A., Salam, R., Dimyati, A., \&amp; Bandriyana. (2015). Studi Scanning Electron Microscopy (SEM) untuk Karakterisasi Proses Oxidasi Paduan Zirkonium. Jurnal Forum Nuklir (JFN), 9, 44-50.

17. Wu Weither., Jin Yongxin, Fang Bai, and Jin Shouguang. (2015). Molecular Medical Microbiology (Second Edition) : Pseudomonas aeruginosa. Science direct. 2, 753767 